\title{
The Development of Exemplary Teaching Practices in Reading Instruction among Five Francophone Teachers
}

\author{
CATHERINE TURCOTTE \\ Université du Québec à Montréal
}

\section{Introduction}

The increasing demands for literacy in our complex society have urged both researchers and practitioners to deepen our understanding of effective reading instruction in the primary grades. Hence, past studies have revealed numerous practices that characterize effective teaching of reading in these grades (Bloch, Oakar \& Hurt, 2002; Taylor, Peterson, Pearson \& Rodriguez, 2002). However, despite the priceless contribution these results have offered, some new questions have emerged and remain essential for supporting teachers in the formation of effective practices. In short, scholarly and teachers' communities are now interested in listening to teachers so as to better understand how they construct their effective practices. Indeed, according to Allington, Johnston and Day (2002), it is now time to support exemplary practices in every classroom. By using phenomenological interviews with five primary teachers identified as exemplary to foster reading achievement and engagement, this study aims to better understand experiences and conditions that lead to effectiveness.

\section{Literature Review}

Studies related to effective reading instruction in the primary grades use various methods such as observation (Bloch, Oakar \& Hurt, 2002; Connor, Morrison \& Petrella, 2004; Taylor, Peterson, Pearson \& Rodriguez, 2002; Turcotte, Giasson \& Saint-Laurent, 2004), field note-taking (Allington, Johnston \& Day, 2002), interviews (Strommen \& Mates, 2004), surveys (Ivey \& Broaddus, 2001; Pressley, Rankin \& Yokoi, 1996), largescale data analysis (Simon \& Turcotte, 2007), and program implementation (Guthrie \& McCann, 1998; Menon \& Hiebert, 2005). Despite their methodological differences, they all come to similar conclusions: using a balanced teaching approach in which reading strategies are taught explicitly inside authentic reading activities, differentiating instruction to sustain all students' learning, providing a rich print environment, and using multiple methods, texts and reading activities to foster both reading comprehension and engagement are exemplary practices that benefit the majority of young readers.

According to Pressley (2006), a balanced teaching approach is not a "tool kit" since it needs to be adapted to the context. As an example, for beginner readers, different word identification strategies are explicitly taught with a concern for transferring these skills and strategies with authentic experiences of text reading (Juel \& Minden-Cup, 2000). For older readers, more high-level reading comprehension strategies, such as inferences or analyses, are explicitly taught or modeled while reading texts of interest (Taylor, Peterson, Pearson, \& Rodriguez, 2002). This balanced teaching approach offers reading tasks inspired by students' interests and current topics. They engage students in a large variety of literary and content area readings (Guthrie \& McCann, 1998; Pressley, 2006), which leads to 
discussions and interactions about reading (Guthrie \& McCann, 1998). Readers are also engaged in individual, small group and large group activities (Morrow, Tracey, Woo, \& Pressley, 1998). More specifically, effective teachers are found to use levelled books to teach reading workshops to small, homogeneous groups (Fountas \& Pinnell, 1996; Juel \& Minden-Cupp, 2000). This needs frequent monitoring, adjusted scaffold intervention (Morrow, Tracey, Woo, \& Pressley, 1998) and various reading material (Pressley et al., 2001). Indeed, their classroom is a print-rich environment that provides easy-to-difficult books for every reader's interests (Block, Oakar, \& Hurt, 2002; Pressley, 2006). Their rich classroom library is also completed with clearly visible students' writing projects and reading strategies boards (Morrow, Tracey, Woo, \& Pressley, 1998). Effective teachers in reading are also found to be engaged readers who share their personal reading habits and thoughts on a daily basis (Ruddell, 2004). As well, studies show that teachers who are engaged readers are most likely to use effective teaching practices (Morrison, Jacobs \& Swinyard, 1999; Ruddell, 2004) and to have long-term effects on their students (Applegate \& Applegate, 2004; Strommen \& Mates, 2004). All of these studies have been significant during the last few decades in bringing about a better understanding of exemplary teaching of reading.

What encourages the formation of exemplary practices is not often treated in these articles because their main interest is examining or comparing practices. Hence, there is still little known about the role reading has played in the teachers' lives (Commeyras, Bisplinghoff \& Olson, 2003), about how teachers become exemplary models for teaching reading (Block, Oakar \& Hurt, 2002), and about the kind of professional development that fosters the development of effective teaching practices in reading (RAND, 2004). Lived experiences and the meaning (Denzin, Lincoln \& Giardina, 2006) exemplary teachers make of their practices would bring new information.

\section{The Professional Identity Framework}

When teachers build practices, they are not only learning new approaches or actions, but also constructing their professional identity (Charlier \& Charlier, 1998). According to Beijaard, Meijer \& Verloop's (2003) review of research studies, professional identity is an ongoing process, evolving along with the interpretation and reinterpretation of experiences. It comes from the interaction of contextual and personal conditions, and is made of subidentities related to teachers' different contexts of action. To form the core of professional identity, these sub-identities should be harmonious rather than conflictual. This identity is also shaped while experiencing and being engaged in professional development.

Hence, research on practices and professional identities must examine both the person and the context, given that being a teacher is a dynamic process integrating these dimensions. In conclusion, the concept of professional identity provides an interesting frame to study the formation of teaching practices, since it takes into account elements from the heterogeneity of personalities, contexts and paths of formation (Anadón, Bouchard, Gohier \& Chevrier, 2001). By listening to how teachers explain and justify their practices in relation to their history and context, practices and professional identity can be better understood (Coldron \& Smith, 1999).

\section{Methods}

In order to better understand how teachers build their practices and how they express their professional identity, this study adopts a constructivist (Le Moigne, 1995) frame of 
reference. This frame illustrates how reality is constructed and how it evolves through the personal experiences of the participants (Seidman, 2006). It assumes that knowledge, beliefs and values are situated and constructed by participants in context (Purcell-Gates, 2004).

According to Clandinin and Connelly (2000), narrative inquiry is suited to studying personal and social interactions because it takes into consideration the notions of continuity and context of experiences. In addition, people generally use storytelling and narrative to construct meaning out of their experiences (McAdams, 1993; Riessman, 1993). The method chosen is that of Seidman's phenomenological interview because it provides direct access to participants meaning-making of their experiences (Seidman, 2006). According to Seidman (2006), people's behaviour becomes understandable when placed in the context of their lives. When they reconstruct their experience, they frame some aspect of it in a narrative way to make it meaningful. To better understand practices and identity, the Seidman's protocol was used because the meaning making process is at the center of the attention.

\section{Participants}

The five participants are Francophone elementary school teachers from the province of Quebec, Canada. In accordance with other research (Allington, Johnston, \& Day, 2002; Morrow, Tracey, Woo \& Pressley, 1999; Ruddell, 2004), they were nominated by their elementary school principals and literacy coaches as particularly successful in promoting reading engagement and in enabling the majority of their students to become competent readers. As well, principals and coaches received a list of exemplary practices based on recent research in the field reported in the literature review of this article in order to guide their selection of nominees. All participants have an undergraduate degree in education and between 6 and 12 years of teaching experience. They all attend various workshops about teaching reading provided by their school board. Hélène (all names are pseudonyms) taught Grades 1 to 6, Marc and Charlotte taught Grade 6, and Geneviève and Dominique both taught Grades 1 and 2. In Quebec, Grade 6 is the last year of the elementary school program. Due to their extensive professional development involvement, the participants were considered models by their colleagues. For instance, some of them have published high-quality pedagogical material; some have received awards or other recognition for their teaching success; and others have provided various workshops about reading instruction to their peers.

To assess the consistency of participants' teaching practices with the criteria articulated in the literature review, the researcher asked school principals and coaches to write a description of their nominees' practices as observed during a school week.

\section{Data Collection}

The Seidman (2006) phenomenological protocol consists of three 60-minute individual interviews. The first interview focuses on the participants' past experiences in their social and professional lives in order to put their practices into context (Seidman, 2006). The main prompt was: "Describe your life and professional experiences that contributed to your teaching practices." The second interview examines the details of their current experience as teachers. It describes the details of their daily experiences with students to better understand practices and internal and external conditions contributing to 
the development or growth of their practices. Recreating the details of their daily experiences allowed the author to check whether their reported practices are in accordance with the ones reported by the principals or coaches and by the literature review. The two following questions led this interview: "Describe your daily teaching practices in reading instruction" and "How do you maintain the efficiency of your teaching?" Finally, the third interview explores participants' constructions or interpretations of meaning of their experiences, as they were also asked to comment on the different experiences and conditions essential to building their practices. Hence, the last interview focused on this question: "What are the meanings that you make out of the experiences you recounted on the first two interviews?"

\section{Data Analysis}

The audio-taped interviews were from days to a week apart, which allowed the researcher and participant time to reflect, while not losing the connection (Seidman, 2006). Each tape was then transcribed verbatim, and its main themes were summarized in a table. At the beginning of the second and third interview, each participant was asked to expand or clarify the table and any theme from the last interviews. Hence, the data analysis included both researcher and participants. When the three interviews were completed, the researcher showed the participant the final themes emerging from the tables to assess their relevance and relative importance. Each participant was asked to contribute to the accuracy of his reported experience. This prolonged engagement allowed both the researcher and the participant to reconstruct and reflect on what is to be learnt and represented from the interviews, which is, according to Lincoln and Guba (1985), one of the most important techniques to ensure credibility.

From this data, a profile was crafted for each participant. Profiles are narratives using the words of the participant and detailing his experience and the meaning he makes of it. They are a shorter version of what the teachers said verbatim. According to Seidman (2006), the crafting of such self-contained narratives serves as a first-degree analysis since it contains the essence of the participant's experience by using his own words. In this research, a second-degree analysis is necessary to identify similarities and differences between the profiles. To ensure credibility and triangulation of this comparative analysis, two qualitative researchers in the field of literacy education were asked to read the profiles and isolate emergent themes. Those identified by the two researchers are presented in this article in the comparative analysis sections.

In addition, the written nominations by their literacy coaches and superiors, the relevance of their nomination as checked at the time of the interviews, the teachers' participation in the analysis of verbatim contents, the techniques used to ensure credibility an triangulation as well as the saturation of the data contained in the profiles, work together to give a comprehensive portrait of this group of exemplary teachers.

\section{Findings}

Following a comparative analysis of participants' reading instructional practices, these findings first present each participant's profile to provide direct information on the contexts and conditions that foster the development of the teachers' practices. They were translated from French into English by two professional translators working in the field of education. These findings outline the comparative analysis of practices and how practices 
developed over time. Although the profiles showed very different life experiences, the comparative analysis illuminates important conditions shared by participants. Personal engagement in reading, in professional development and in reflection upon practice was found in every profile. As for contextual conditions, all participants found professional support and reading models to be a determining factor in their formation of practices.

\section{Comparative Analysis of Practices}

In order to put the profiles into context, Table 1 presents the teachers' practices as self-reported and as described by their principal or literacy coach. These practices are also found to be consistent with the literature review on exemplary practices presented in this article. 
Table 1

Teachers' Practices as Observed by School Principal or Literacy Coach

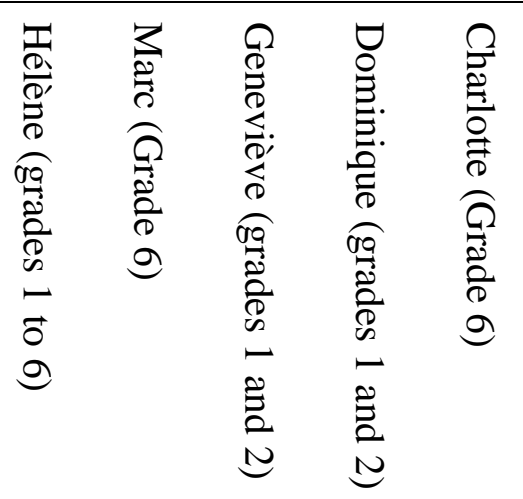

\section{Preferred reading instruction practices}

Teaches phonics explicitly while reading texts

Models reading strategies using thinking aloud

$\begin{array}{llll}X & & X & X \\ X & X & & X \\ X & X & X & X\end{array}$

Teaches comprehension strategies while reading

$\mathrm{X}$

texts

Teaches high-level strategies with older students $\quad$ X $\quad$ X

$\mathrm{X}$

(inferences, analyses, critics)

Discussions and interactions are highly supported $\quad X \quad X$

$\mathrm{X}$

among older students

\section{Ways of sustaining learning}

Small homogeneous groups

Levelled reading workshops

Frequent monitoring of learning difficulties

Different levels of scaffolding according to

reader

$\begin{array}{llllllll}\text { Different reading material according to readers' } & X & X & X & X & X\end{array}$

level

\section{Print environment}

Books for beginner to grades 3-4

Books for beginner to adolescent readers

Students' writing is clearly visible

Reading strategies are visible and referred to

Promotion of books and other reading material

Presence of a rich classroom library

Organization and management

$\begin{array}{lllllll}\text { Tasks inspired by students interests and current } & X & X & X & X & X\end{array}$ topics

Engage students in reading a large variety of texts

Plans individual, small groups and large group

reading activities

Behaviour toward reading

$\begin{array}{lllllll}\text { Shares thoughts about personal reading every day } & X & X & X & X & X\end{array}$

Shares newspaper article every morning

$\begin{array}{lllll} & & \text { X } & \text { X } & \\ \text { X } & \text { X } & & & \text { X } \\ \text { X } & \text { X } & \text { X } & \text { X } & \text { X } \\ \text { X } & \text { X } & & \text { X } & \\ \text { X } & \text { X } & \text { X } & \text { X } & \text { X } \\ \text { X } & \text { X } & \text { X } & \text { X } & \text { X }\end{array}$

$\begin{array}{lllll} & X & & X & X \\ X & X & X & X & X\end{array}$

$\begin{array}{lllll}X & & X & X & \\ & & X & & \\ X & X & X & X & X \\ & & X & X & \end{array}$


As shown in Table 1, the participants all used explicit teaching of skills and strategies within authentic reading tasks. They also sustained their readers' progress by providing differentiated scaffolding strategies. These five elementary teachers provided a large variety of texts and levels of reading, while creating authentic writing and interaction opportunities. They exploited students' interest to maintain engagement and plan different kinds of grouping to better assist struggling readers, for example, during small-group instruction. They modelled strategies as well as their own engagement in reading by sharing their thoughts and values about reading.

As stated above, these practices are described in existing research on exemplary teaching of reading. In fact, the integration of these different practices is considered a balanced approach (Pressley, 2006). Yet, the goal of our study was to go further and develop a better understanding on how these exemplary practices are constructed among elementary teachers by comparing their profiles. These profiles are narrated in the following section.

\section{Teacher Profiles}

Hélène's profile.

When I was a child, reading was everywhere in the house, because both my parents and my brothers were active readers. Unfortunately, my school experiences were not that rich. I feel so disappointed that I never had any inspiring teachers to foster my love of reading during those years. Thanks to my family, I am an avid reader even today. When I studied education at the university, I met a teacher who was really engaged in reading. She even gave a different poem to each one of her 75 students. When I became a teacher myself, I really reinvested in this idea. I personalized reading suggestions for every child in my class. If you do believe this can make a difference, you are willing to spend time looking for books to match each of your students.

Not having had a good inspiring experience during elementary and high school helped me build my own practices. Funny as it may seem, I wanted to break that circle, to break this non-motivational climate in my classroom. I had to innovate and create a rich environment in which teaching would be as motivating as it was effective. To do so, I had to be a model, just like my parents and my university professor. This is where I started. I always presented texts and books I really liked, and then I helped children learn how to read, to reflect, to understand and to use reading strategies in context. With older students, we can explore many skills expected in the curriculum by reading and discussing about our text. In my school, we value balanced teaching of reading, and I am fully involved in it. I like to use a lot of books and authentic texts to teach phonics and comprehension strategies in context. Sometimes, I need to do mini-lessons to teach particular skills or strategy. For example, I have a "sound" chart in class that helps us with letter-sound correspondence. We refer to it many times a day while reading and writing, especially when I work with at-risk readers in small groups. I believe all these actions help my students have better strategies with writing words for the beginners, and with comprehension for the older readers. Having authentic texts and more explicit reading activities gives me the opportunity to constantly monitor each student's progress.

When I arrived in my school, the principal really gave me a lot of latitude. She told me, "We have to increase understanding AND motivation in reading." She gave me time to explore new practices. I am very lucky because both my parents are former teachers, and we talk about teaching every time we see each other. They are kind of colleagues, but with a lot 
of experience! Furthermore, I read articles and books about teaching reading in an effective way. I want my approach to be coherent with who I am and what I believe learning is. It's necessary for me to stop and reflect upon what I do. Then, I can easily readjust and innovate. I consider it is my responsibility to make good readers; readers that can understand, discuss, link what they learn to other domains, and be critical.

\section{Marc's profile.}

To start with, I have to admit I hated reading when I was a child. Nobody liked it in my family. The first things I had to read were schoolbooks, and I hated them. I also never had an engaged teacher. I can't even tell you the name of a teacher who inspired me to read or do anything in life that made sense. School was just something compulsory.

My first significant reading experience took place while I was attending high school. My girlfriend belonged to a group of friends who were avid readers of novels, and they would always discuss books they liked. I realized I was missing something so I asked my girlfriend to suggest a good book to me. She suggested "Prince of Tides". From this moment onward, I started reading. I understood one could learn and enjoy the experience with books. Furthermore, I could participate in discussions about the books, and I felt much better. Interactions about reading always motivated me. I guess that, when you have a start like mine, and you come all the way up to becoming an avid reader, you are the best person to teach reading to others. That is why I promote reading. I buy a large number of quality books, I set up a nice reading environment and model how engaged I am in reading. I try to change things and make learning more interesting for children. I can't see myself repeating over and over the same things year after year. That would neither be learning nor interesting for me.

Every day, I read the newspaper with my students, and we discuss a topic. In my classroom, we do not only learn how to read, we learn through reading, we learn to criticize ideas, to create identities. All this is very important in our rural context where children are not motivated to read or even to develop their critical reflection. The newspaper activities are vital to developing vocabulary, reading strategies and critical reflection. In order to stimulate the more narrative part of reading, I use reading circles. I can see how they foster motivation and meaning-making, as well as develop engagement since the children know they will share what they read.

I don't want my students to be passive readers. I teach reading strategies to develop good comprehension of the text, but I like it much better when we develop higher comprehension skills like analyzing, comparing, debating, etc. This doesn't come naturally. I must keep it up with students from the very first day of school by modeling, asking questions or creating debates to push their basic reactions or comments. Then, we use reading to have good writing models. When you write an article, a story or a poem the readers will be much more interested if you do it respecting a right structure and if you use uncommon and beautiful words, for example. Reading and writing are taught simultaneously.

During my first years of teaching, I was hired as a substitute teacher. This rich experience allowed me to gather several ideas by observing what other colleagues did, and selecting the teaching strategies that best suited me. Reflecting with other teachers brought me a lot at first when everything was new. Then, when I started as a regular classroom teacher, the principal told me that she welcomed reading projects and that there was money 
to buy new books. I was very lucky to receive such support and trust from her. That's when I started reading circles and the newspaper activities. Some parents even told me their child asked them to buy the newspaper every morning so that he could be ready for discussions at school. In my rural school context, this is a revolution!

\section{Geneviève's profile.}

As a child I don't remember being read to or going to the library. My mother was not a model reader; neither were any of my elementary grade teachers. I didn't like to read, and French was my weakest subject. Still, when I was at university, I had a class with Dominique Demers, a child's literacy author. Her classes had a real impact on me. I discovered children's literature, illustrators, and stories. This experience was so fantastic that it still inspires me today. I discovered reading, and have become a compulsive reader.

Since then, I have attended several workshops on teaching reading, and am always looking for new ideas in order to teach better. For example, once I met a teacher who really teaches all her reading content with children's literature. I use some of her strategies, and developed my own, too. Nowadays, I am invited to give workshops to other teachers!

We could say that my school is special in some way, since $80 \%$ of the children are immigrants. As teachers, we soon realized it was impossible to teach these children with textbooks and worksheets, because we needed to differentiate our teaching. Thus, two other first-grade teachers and I worked hard to make our own material, choose our own texts and books, and organize some workshops. Through this collective effort, I can now let better readers work independently, while I supervise a small group of students and help them conquer their reading difficulties.

Sometimes, I work on very isolated skills with immigrant students, like phonics for example. I really have to teach them letter-sound correspondence, because the French language is a really big challenge. However, I can't do only phonics, because children would have a very limited view of what reading truly is. Therefore I buy a lot of levelled book collections and children's literature so that every time we read a story, we use all the strategies we know to identify words, understand small sentences or discover the meaning of an expression; it's a conquest! Writing is also very important to transfer our reading strategies. Some of them can only write small words; some write texts; and others are doing it with a peer tutor, but everybody is a winner because by writing a lot. The progress they make is really noticeable.

Our school principal is dedicated and helpful in sustaining our efforts to experiment with new paths. It took me years of trying new experiences, taking risks, learning with others teachers, as well as reading and reflecting upon my practices to be where I am now. However, I still remind myself that I should do or have done this instead. I take time to think, but it is always so worthwhile!

\section{Dominique's profile.}

My parents were good reading models, because they read every day and encouraged me to read a lot. I have always enjoyed it too. Also, when I was in Grade 6, we had a professor from France, and he made us discover Molière. The text suddenly became alive; it was a completely new experience for me and so significant! I heard that play will be presented at a theatre near here. I want to go along with a former student. I would like to 
give back what I received when I was in Grade 6. I hope this experience will be as meaningful for her as it was for me.

I did my undergraduate degree here in Canada, and I cannot recall the name of any inspiring professor. A few years afterwards, I began to teach and constantly had the feeling that I was not doing everything to help struggling readers. Much later, I decided to go to another country to do a Master's degree with a specialization in reading intervention. There, I met a professor who influenced me a lot. She was very practical, and everything we studied in class still helps me today. She introduced me to children's literature, and gave me the motivation to become an avid reader, too. She was very passionate and loved literature. She made me realize everything I could do with children's literature.

When I came back, one of my colleagues wanted to work with me. We started with school textbooks, and, later on, we realized levelled books and our own material were much more effective. I looked everywhere to find levelled books that would allow me to use small group instruction. I get a lot of ideas from Fountas and Pinnell (1996) or from the fourblocks approach. Even today, I am constantly reorganizing my educational approach. In my classroom, we use levelled books, letters posters, magazines, a word wall, giant texts, and students' writing production. It's very important that children feel reading is a priority. Every week, I plan shared reading with the whole group. I focus on strategies before, during and after reading to develop automatisms. Then, I plan a lot of small-group instruction to work on identified and needed strategies. It can involve word reading strategies, connectors, comprehension of the whole text, summarizing, finding the main idea, understanding the characters, etc. Afterwards, every student reads and writes alone while I am available to help them. I spend a lot of time with each one of them. Next month, we will start a study about an author we like. The goal is to read a large number of books he wrote to compare, reflect, share ideas. Sometimes, I have all the control because I teach directly. I also do interactive writing to share writing strategies. Then, we discuss spelling problems and grammar, which makes learning in these activities rich.

Working with a colleague really pushed me ahead, because we both brought new ideas to try based on research and theories. At the beginning, the school principal helped us find new collections, but, after a few years, a new principal came who didn't believe in our project. I had to fight to get books other than school manuals. I started to realize my approach could be disturbing to some other teachers. It's not everybody who is willing to experiment and reflect upon his/her own practice like I do.

You have to believe that every reader in your classroom is able to get better. It is my responsibility to have such professional awareness. What is different between me and other teachers who are not willing to question their approach is our vision of responsibility. If a child doesn't read well, is there anything I can do to modify this situation? I know it's hard, but it's also rewarding to feel you have certain control over the educational approach, and that, at the end of the year, you know you did everything you could to create good readers.

\section{Charlotte's profile.}

In my family, books were never around and my parents never encouraged us to study. I always wanted to learn and know more but when you have this kind of background, you need to be very determined. It may be because I didn't grow up in a culturally enriched family that I want to create such an environment for the students in my classroom. 
In elementary grades as well as in high school, I did not have the chance to encounter a teacher that fostered the joy of reading. Nonetheless, it was only when I was admitted to the literature program at university that I started enjoying reading and discovered passionate readers among my teachers; some of them still inspire me today. Since then, I am very passionate about reading. I think reading serves learning and vice versa; it opens you up to culture and life. After this certificate, I studied education and met a professor who made me reflect a lot upon my teaching of reading. She said things that really made sense, and I started right away to think about how I would teach. When I started teaching, I soon realized there were a lot of things that didn't work with young readers. One day I met a teacher from another school who had developed his own way of teaching reading by using all kinds of significant books. I felt he put his energies into the essentials: reading and developing lifelong learners. Inspired by this teacher, I started to create my own approach. I really made a 180-degree turn, I decided to write a journal and work with another colleague in order to better reflect how enriching this other way of looking at things could be. These two experiences really helped me understand, criticize and take risks to improve my teaching.

In my Grade 6 classroom, there is no book that is turned down as being too childish, etc. I realize that variety is very important for sixth graders. We read songs and poetry about subjects that pique their interest. They have to read to understand new concepts. I focus a lot on strategies and self-regulation while reading texts from everyday life. In Grade 6, it's essential to monitor your own comprehension, because, in high school, very few reading strategies are taught. Then, we write and integrate everything we have learnt while reading. Every morning, I sit down with them, and we analyze a few writing mistakes. We do grammar in a significant way, not just to learn rules, but also to write our ideas better! It's like a community of learning. We all help each other and are proud of our success. Inside this community, I am the model, and it's my responsibility to be enthusiastic and encourage the love for reading. Each year, I take my class "pulse". I reorient my teaching ideas to better meet their needs and interests. It is impossible for me to teach the exact same way year after year, because each group I have is unique. It seems to me that it's impossible to improve your teaching strategies if you don't reflect upon your daily actions.

\section{Comparative Analysis of the Development of Teachers' Practices}

Although these five teachers have different life stories, many similarities emerged from their profiles. Table 2 shows personal (engagement for reading, engagement for professional development and reflection on practice) and contextual (professional support, inspiring model) conditions important for the building of their practices and professional identities. As stated in the methodology, these conditions were identified by two different researchers and the participants themselves after the interviews. According to Seidman (2006), it is useful to look for connecting threads and patterns among profiles to discover shared conditions. 
Table 2

Teachers' Personal and Contextual Conditions that Foster the Formation of Their Exemplary Teaching Practices of Reading

\begin{tabular}{|c|c|c|c|c|c|}
\hline & Hélène & Marc & Geneviève & Dominique & Charlotte \\
\hline $\begin{array}{l}\text { Personal } \\
\text { condition: } \\
\text { Engagement } \\
\text { for reading }\end{array}$ & $\begin{array}{l}\text { (...) I am an avid } \\
\text { reader even today. } \\
\quad(\ldots) \text { I had to be a } \\
\text { model, just like my } \\
\text { parents and my } \\
\text { university professor. }\end{array}$ & $\begin{array}{l}\text { Interactions about } \\
\text { reading always } \\
\text { motivated me. } \\
\text { That is why I } \\
\text { promote reading. }\end{array}$ & $\begin{array}{l}\quad \text { I discovered } \\
\text { reading, and have } \\
\text { become a } \\
\text { compulsive } \\
\text { reader. }\end{array}$ & $\begin{array}{l}\text { I have always } \\
\text { enjoyed it too. }\end{array}$ & $\begin{array}{l}\quad \text { Since then, I am } \\
\text { very passionate about } \\
\text { reading. I think } \\
\text { reading serves } \\
\text { learning and vice } \\
\text { versa, it opens you up } \\
\text { to culture and life. }\end{array}$ \\
\hline $\begin{array}{l}\text { Personal } \\
\text { condition: } \\
\text { Engagement } \\
\text { for } \\
\text { professional } \\
\text { development }\end{array}$ & $\begin{array}{l}\quad(. . .) \text { it is my } \\
\text { responsibility to } \\
\text { make good } \\
\text { readers }(. . .) \\
\quad \text { I read articles } \\
\text { and books about } \\
\text { teaching reading } \\
\text { in an effective } \\
\text { way. }\end{array}$ & $\begin{array}{l}\quad \text { I try to change } \\
\text { things and make } \\
\text { learning more } \\
\text { interesting for } \\
\text { children. I can't see } \\
\text { myself repeating over } \\
\text { and over the same } \\
\text { things year after year. } \\
\quad(. . .)(\mathrm{I}) \text { gather } \\
\text { several ideas by } \\
\text { observing what other } \\
\text { colleagues did and } \\
\text { selecting the teaching } \\
\text { strategies that best } \\
\text { suited me. }\end{array}$ & $\begin{array}{l}\text { (...) I have attended } \\
\text { several workshops on } \\
\text { teaching reading, and } \\
\text { am always looking for } \\
\text { new ideas in order to } \\
\text { teach better. }\end{array}$ & $\begin{array}{l}\quad(. . .) \text { I decided } \\
\text { to go to another } \\
\text { country to do a } \\
\text { master degree } \\
\text { with a } \\
\text { specialization in } \\
\text { reading } \\
\text { intervention. }\end{array}$ & $\begin{array}{l}\quad \text { I decided to } \\
\text { write a journal } \\
\text { and work with } \\
\text { another colleague } \\
\text { in order to better } \\
\text { reflect how } \\
\text { enriching this } \\
\text { other way of } \\
\text { looking at things } \\
\text { could be. }\end{array}$ \\
\hline $\begin{array}{l}\text { Personal } \\
\text { condition: } \\
\text { Reflection on } \\
\text { practice }\end{array}$ & $\begin{array}{l}\quad \text { I read articles and } \\
\text { books about teaching } \\
\text { reading in an effective } \\
\text { way. (...) It's } \\
\text { necessary for me to } \\
\text { stop and reflect upon }\end{array}$ & $\begin{array}{l}\text { Reflecting with } \\
\text { other teachers brought } \\
\text { me a lot at first when } \\
\text { everything was new. }\end{array}$ & \begin{tabular}{l}
\multicolumn{1}{c}{ It took me } \\
years of trying \\
new experiences, \\
taking risks, \\
learning with \\
others teachers,
\end{tabular} & $\begin{array}{l}\quad \text { Even today, I am } \\
\text { constantly } \\
\text { reorganizing my } \\
\text { educational approach. } \\
\text { It's not everybody } \\
\text { who is willing to }\end{array}$ & $\begin{array}{l}\text { It is impossible for } \\
\text { me to teach the exact } \\
\text { same way year after } \\
\text { year (...) } \\
\text { (...) it's impossible } \\
\text { to improve your }\end{array}$ \\
\hline
\end{tabular}


what I do.

\begin{tabular}{ll}
$\begin{array}{l}\text { Contextual } \\
\text { condition: }\end{array}$ & \multicolumn{1}{c}{ She (the school } \\
principal) gave me \\
Professional \\
support & $\begin{array}{l}\text { time to explore new } \\
\text { practices }\end{array}$ \\
& (...) we (Hélène \\
& and her parents) talk \\
& about teaching every \\
& time we see each \\
& other.
\end{tabular}

\section{(...) both my} parents and my brothers were active readers.

(...) I met a teacher who was really engaged in reading.

(...) I really reinvested in this idea. as well as reading and reflecting upon my practices to be where I am.

\section{(...) the principal} told me that she welcomed reading projects and that there was money to buy new books. I was very lucky to receive such support and trust from her.

\section{My girlfriend} belonged to a group of friends who were avid readers of novels, and they would always discuss books they liked.$$
\text { (...) other first- }
$$
grade teachers and I worked hard to make our own material (...)

\section{Our school} principal is dedicated and helpful (...)

(...) when I was at university, I had a class with Dominique Demers, a child's literacy author. Her classes had a real impact on me. (...) This experience was so fantastic that it still inspires me today.

experiment and reflect teaching strategies if upon his/her own practice like I do. you don't reflect upon your daily actions.

$\begin{array}{ll}\begin{array}{c}\text { Working with a } \\ \text { colleague really } \\ \text { pushed me ahead (...) } \\ \text { At the beginning, }\end{array} & \begin{array}{l}\text { One day I met a } \\ \text { teacher from another } \\ \text { school who had }\end{array} \\ \text { the school principal } & \text { way of teaching } \\ \text { helped us (...) but } & \text { reading (...) Inspired } \\ \text { after a few years, a } & \text { by this teacher, I } \\ \text { new principal came } & \text { started to create my } \\ \text { who didn't believe in } & \text { own approach. }\end{array}$

our project.

My parents were good reading models (...)

(...) we had a professor from France, and he made us discover Molière.

(...) it was a completely new experience for me and so significant!

There (University) I met a professor who influenced me a lot.

(...) She was very

passionate and loved literature. 
This last table shows that all participants describe a high level of engagement with reading. They all recounted meaningful experiences that leaded them to be engaged readers for years. As well, to be engaged in their professional development is also decisive for these five teachers. While Hélène describes her professional development to be sustained by her commitment to make good readers, Marc and Geneviève report how important it is for them to teach better in order to make learning more interesting and meaningful. Dominique and Charlotte both worked hard to attain professional development in another country or by exploring other teachers' practices and keeping a personal journal. They also mention the importance of reflection in order to evaluate their practices and improve them. Some participants read articles or books to maintain reflection (Hélène, Charlotte), some take pedagogical risks, experiment new practices, reorganize their practices (Dominique, Geneviève) and some find ways to reflect individually or with colleagues upon their teaching strategies and actions (Hélène, Marc, Charlotte). These last results show that these personal conditions are shared by participants. They all recounted personal experiences under these conditions as being meaningful in the construction of their exemplary practices.

The results also show some shared contextual conditions. According to these participants, support from colleagues is another important condition. Colleagues can be either parents (Hélène), peers from the same school (Marc, Geneviève, Dominique, Charlotte) or from other schools (Charlotte). While school principals sometimes encouraged teachers to try new teaching strategies and to focus on reading, Charlotte did not mention any contribution on the part of her principals in the formation of her effective practices. As for Dominique, while one principal supported her initiatives, a second one did not believe in what she did and was not helpful. The influence of supportive and active colleagues appears to be determinant in each profile.

Reading models can be found everywhere in these teachers' profiles. For some of them, models were in the immediate family (Hélène, Dominique); for Marc, secondary school, and, for Dominique, an elementary teacher played a major role. However, Geneviève and Charlotte had to wait until university before encountering a reading model that would inspire them. The role of a university professor as a reading model was also crucial in Dominique's and Hélène's experience.

Personal and contextual conditions are found to be important in every participant's experience. They might share similar personal conditions such as being an engaged reader, being involved in professional development experiences and in reflective practices, but they all recounted them in very different and unique ways. Contextual experiences are also different in every participant's story, but they are similar enough to connect these experiences and classify them under specific themes.

These results highlight the importance of personal and contextual conditions for shaping or influencing the growth of exemplary teaching practices in the field of reading. Now that this understanding is clearer, the discussion and conclusions can focus on what needs to be implemented to better foster the formation of effective practices in reading instruction among elementary-grade teachers.

\section{Discussion}

The results of this research are of utmost importance to understanding crucial conditions that contribute to build exemplarity and determine the implications they have in the training of future teachers as well as of those already in practice. Research and teaching 
communities would highly benefit from studies focused on practices specific to Francophone students' and teachers' contexts. This study represents only a first initiative.

Recent studies reveal practices of exemplary teachers of reading in the primary and elementary grades. This research went further in presenting how participants' practices were strongly tied to past and present experiences of engagement, reflection, professional support and reading models. The phenomenological interviews provided direct access to links between experiences, practices and the meaning teachers make of them.

The exemplary teachers in this study adopted a balanced teaching approach that reflects what is described in the literature review. They provided every reader with appropriate and significant reading material, since they use multiple strategies and actions to foster word identification, comprehension and engagement in reading. These strategies differed from one teacher to another since the decisions depended on the grade they taught. Hence, such a balanced approach is founded on the teacher's own knowledge, professional experience, reflection, motivation and assessment of students (Pearson, 2004; Pressley, 2006). Since balanced teaching is not reproducible from one context to another, these teachers used their knowledge of the reading development and acquisition of every student to foster an approach directly adapted to their needs.

Teachers in this study also reflected on their practices and actively engaged in improving them. In fact, this study shows that using a balanced teaching approach is inseparable from developing engagement and skills in reflection on practice. All five participants were actually engaged in various form of reflection individually and with others in order to improve their teaching practices and create the best learning contexts for their young readers. They described many opportunities to exchange with peers, to learn from excellent reading and teaching models, and to reflect, compare and discuss practices to stimulate new practices. Studies (Butler, 2005; Snow-Gerono, 2005) carried out in various educational fields confirm that sharing and reflecting with peers encourage teachers to work together, take pedagogical risks, reflect upon their own experience and interact with other professionals. In sum, to build exemplary practices that guide the majority of students to success in reading, teachers must develop a good knowledge of balanced teaching, but they must also keep learning and reflecting on their own and with others to improve their practices and to better meet their students' needs and interests. Teachers from this study were not used to Seidman's (2006) phenomenological interviews, but they were used to expressing and reinterpreting their experiences and practices, which encouraged them to experiment and to become more efficient in reading instruction. Building links between the two first interviews was actually easy for them since they already had developed capacities and openness to reflect on their professional life. Since this is not always the case for all practitioners or teachers candidate, narratives could be a interesting start to improve reflection about past and present reading and teaching experiences. As evidenced in this study, through storytelling, human beings are naturally drawn to meaning making and to interpretation of their own actions. For that reason, the third interview of the Seidman's protocol (2006) is crucial since it brings the participants to reflect on the meaning of their recounted experiences, to explicit the links between past and present experiences and to describe the emotional and intellectual connections between their personal experiences and professional practices (Seidman, 2006). As examples, participants consider that "Not having had a good inspiring experience during elementary and high school helped me build my own practices" (Hélène); or "when you have a start like mine, and you come all the way up to 
becoming an avid reader, you are the best person to teach reading to others" (Marc); or also "I would like to give back what I received when I was in Grade 6" (Dominique). These extracts from the profiles suggest that connections between personal and professional life are important in the way teachers build their practices and that reflecting on these connections brings a richer and deeper understanding of teachers' identities.

In addition, narratives are viewed as one of humans' favourite ways to build meaning from their experiences and also as an excellent means to share one's experience with peers (Clandinin \& Connelly, 2000). The profiles presented in this research, written verbatim, are indeed very accessible to all elementary teachers who ask themselves how other colleagues teach and construct their teaching approaches. For teachers to be, as well as for full-fledged practitioners, narratives represent a powerful tool to induce reflection and exchanges, which in turn could lead to the improvement of practices.

Results from previous studies in reading instruction (Applegate and Applegate, 2004) or in other educational fields (Anadón, bouchard, Gohier, \& Chevrier, 2001; Jones, Armour \& Potrac, 2003), as well as many extracts from the profiles also lead to the conclusion that having access to inspiring models of readers or practitioners inspire reading commitment and/or effective teaching practices. In this study, Marc, Charlotte and Geneviève did not have reading models in their childhoods, at home or in elementary school. Fortunately, these three participants met reading models later in high school or even much later while studying in university. This study shows that even if some future teachers are not enthusiastic readers or potential reading models for students, teacher education programs and continuing education might be the last, but certainly not the least of opportunities for them to become engaged readers and exemplary practitioners. This contextual condition appeared to be decisive in all the profiles of this study. The benefits of developing engaged and good reading models among future teachers are exponential since they will, in turn, promote reading engagement and foster excellent reading skills among their students. Hence, this study highlights the fact that developing good teaching skills and competencies, as well good reading habits, positive attitudes toward reading and long-term reading engagement among teacher candidates must become a priority.

Lastly, if school and preservice teacher education programs create conditions focused on reflection, engagement, sharing, mentoring, and professional development, teachers will feel welcome to engage in improving their practices, develop their professional identity and nurture a rich learning environment that will lead to constant improvement and countless benefits for young readers. Training for teachers should also model quality reading activities, such as reading high-quality texts, exchanging interpretations with others or observing a strategic reader. Although time and resources to create these external conditions might sometimes seem considerable, this study shows that they greatly benefit the school community. Eventually, continuing professional education should be directed not only to teachers but also to those responsible for effective literacy programs such as principals and coordinators. University professors, member of school administration and teachers would all benefit from a long-term collaboration. This would enhance reflection and the quality of instruction in bringing innovative practices based on current research and challenges met in the classroom. By sharing and confronting ideas, thoughts and experiences about reading education, practitioners, administrators and researchers could develop a better understanding of this particular and crucial learning in different settings. 
Allington, R.L., Johnston, P.H., \& Day, J.P. (2002). Exemplary fourth-grade teachers. Language Arts, 79, 462-466.

Anadón, M., Bouchard, Y., Gohier, C., \& Chevrier, J. (2001). Interactions personnelles et sociales et identité professionnelle. Revue canadienne de l'éducation 26, 1-17.

Applegate, A. J., \& Applegate, M. D. (2004). The Peter effect: Reading habits and attitudes of preservice teachers. The Reading Teacher, 57, 554-563.

Beijaard, D., Meijer, P.C., \& Verloop, N. (2004). Reconsidering research on teachers' professional identity. Teaching and Teacher Education 20, 107-128.

Block, C.C., Oakar, M., \& Hurt, N. (2002). The expertise of literacy teachers: A continuum for preschool to grade 5. Reading Research Quarterly, 37, 178-206.

Butler, D. (2005). L'autorégulation de l'apprentissage et la collaboration dans le développement professionnel des enseignants. Revue des sciences de l'éducation, 31, 55-78.

Charlier, E., et Charlier, B. (1998). La formation au coeur de la pratique . Bruxelles: De Boeck.

Clandinin, D. J., \& Connelly, F.M. (2000). Narrative inquiry. San Fransisco, Josey-Bass.

Coldron, J., \& Smith, R. (1999). Active location in teachers' construction of their professional identities. Journal of Curriculum Studies, 31(6), 711-726.

Commeyras, M., Bisplinghoff, B.S., \& Olson, J. (2003). Teachers as readers. Newark, DE: International Reading Association.

Connor, C.M., Morrison, F.J., \& Petrella, J.N. (2004). Effective reading comprehension instruction: Examining child X instruction interactions. Journal of Educational Psychology, 96, 682-698.

Denzin, N.K., Lincoln, Y.S., \& Giardina, M.D. (2006). Disciplining qualitative research. International Journal of Qualitative Studies in Education, 19, 769-782.

Fountas, I.C., \& Pinnell, G.S. (1996). Guided reading: Good first teaching for all children, Portsmouth, NH, Heinemann.

Guba, E.G., \& Lincoln, Y.S. (1994). Competing paradigms in qualitative research, in: N.K. Denzin \& Y.S. Lincoln (Eds.), Handbook of Qualitative Research (pp. 105-117). Thousand Oaks: Sage.

Guthrie, J.T., \& McCann, A.D. (1998). Characteristics of classrooms that promote motivation and strategies for learning,. In J.T. Guthrie \& A. Wigfield (Eds.), Reading engagement. Motivating readers through integrated instruction (pp. 128-148). Newark, DE: International Reading Association.

Ivey G., \& Broaddus, K. (2001). "Just plain reading": A survey of what makes student want to read in middle school classrooms. Reading Research Quarterly, 36, 350-377.

Jones, R.L., Armour, K.M., \& Potrac, P. (2003). Constructing expert knowledge: a case study of a top-level professional soccer coach. Sport, Education and Society, 8, 213-229.

Juel, C., \& Minden-Cupp, C. (2000). Learning to read words: Linguistic units and instructional strategies. Reading Research Quarterly, 35, 458-492.

Kelchtermans, G. (2001). Formation des enseignants. L'apprentissage réflexif à partir de la biographie et du contexte. Recherche et formation, 36, 43-67.

Le Moigne, J.L. (1995). Les épistémologies constructivistes. Paris: PUF.

Lincoln, Y. S., \& Guba, E. G. (1985). Naturalistic inquiry. Beverly Hills: Sage Publications.

McAdams, D.P. (1993). The stories we live by. New York: Guilford Press.

Menon, S., \& Hiebert, E.H. (2005). A comparison of first graders' reading with little books or literature-based basal anthologies. Reading Research Quarterly, 40, 12-38. 
Morrison, T. G., Jacobs, J. S., \& Swinyard, W. (1999). Do teachers who read personally use recommended literacy practices in their classrooms? Reading Research and Instruction, 38, 81-100.

Morrow, L. M., Tracey, D. H., Woo, D., \& Pressley, M. (1999). Characteristics of exemplary first-grade literacy instruction. The Reading Teacher, 52, 462-476.

Pearson, D. (2004). The reading wars. Education Policy, 18, 216-252.

Perrenoud, P. (2000). De la pratique réflexive au travail sur l'habitus. Recherche et formation, $36,131-162$.

Pressley, M., Rankin, J., \& Yokoi, L. (1996). A survey of instructional practices of primary teachers nominated as effective in promoting literacy. Elementary School Journal, 96, 363-384.

Pressley, M., Wharton-McDonald, R., Allington, R., Block, C. C., Morrow, L., Tracey, D., Baker, K., Brooks, G., Cronin, J., Nelson, E., \& Woo, D. (2001). A study of effective first-grade literacy instruction. Scientific Studies of Reading, 5, 35-58.

Pressley, M. (2006). Reading instruction that works. The case for balanced teaching $\left(3^{\text {rd }} \mathrm{Ed}\right)$. New York: Guilford.

Purcell-Gates, V. (2004). Ethnographic Research, in: N.K. Duke \& M. H. Mallette (Eds.), Literacy research methodologies (pp.92-113). New York: Guilford.

RAND. (2004). A research agenda for improving reading comprehension. In R.B. Ruddell, and N.J. Unrau (Eds.), Theoretical models and processes of reading $5^{\text {th }}$ Edition (pp.720-754). Newark: International Reading Association.

Riessman, C.K. (1993). Narrative Analysis. Newbury Park: SAGE publications.

Ruddell, R.B. (2004). Researching the influential literacy teacher: characteristics, beliefs, strategies, and new research directions, in: R.B. Ruddell \& N.J. Unrau (Eds.), Theorical models and processes of reading $5^{\text {th }}$ Edition (pp.979-997). Newark: International Reading Association.

Seidman, I. (2006). Interviewing as Qualitative Research. 3rd Edition. New York: Teachers College Press.

Simon, M., et Turcotte, C. (2007). Rôle du facteur linguistique dans les pratiques pédagogiques rapportées au programme international de recherche en lecture scolaire (PIRLS). Les Actes du 19ième colloque de l'ADMEE.: http://jemacs.uni.lu/index.php/JEMACS/article/viewFile/96/96

Snow-Gerono, J.L. (2005). Professional development in a culture of inquiry: PDS teachers identify the benefits of professional learning communities. Teaching and Teacher Education, 21, 241-256.

Strommen, L.T., \& Mates, B.F. (2004). Learning to love reading: interviews with older children and teens: Journal of Adolescent and Adult Literacy, 48, 188-201.

Taylor, B. M., Peterson, D. P., Pearson, P. D., \& Rodriguez, M. C. (2002). Looking inside classrooms: Reflecting on the "how" as well as the "what" in effective reading instruction. The Reading Teacher, 56, 270-279.

Turcotte, C., Giasson, J., \& Saint-Laurent, L. (2004). La relation entre le style d'intervention de l'enseignante en lecture et le progrès des élèves à risque en première année du primaire. McGill Journal of Education, 39, 2, 183-199. 


\section{AUTHOR BIOGRAPHY}

Catherine Turcotte is a professor at the Université du Québec à Montréal in the department of specialized education and formation. She is interested in understanding factors contributing to the success of struggling readers from kindergarten to middle school. She is also engaged in various collaborative projects in order to sustain exemplary reading instruction. 